\title{
Coronavirus Disease and Abdominal Pain: Mechanism, Diagnostic, and Treatment
}

\author{
Aleksandra Bozhinovska*(D) \\ Department of Surgery, City General Hospital 8 September, Skopje, Republic of Macedonia
}

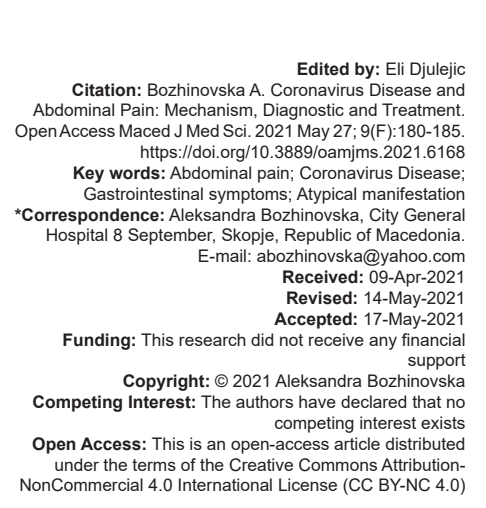

Introduction

Severe and acute abdominal pain is almost always a symptom for intra-abdominal disease that requires a surgical treatment (condition termed as acute abdomen). From a pathophysiological perspective, abdominal pain is divided as visceral, somatic, and referred pain.

Recent studies indicate that coronavirus disease (COVID-19) can also be a possible cause of abdominal pain. According to Widyadharma et al. [1], the mechanism of pain in severe acute respiratory syndrome coronavirus 2 (SARS-CoV-2)-positive patients "is associated with two-way communication between the gut microbiota and the brain, namely, between the endocrine (cortisol), the immune system (cytokines), and nerves (vagus nerve and enteric nervous system)." Namely, ACE2 receptors which are the target of SARS-CoV-2, in humans, are found on the luminal surface of the redifferentiated small intestinal epithelial cells and in crypt and colon cells [1], [2]. It is implied that the described mechanism is the reason for presentation of abdominal pain without respiratory symptoms in some, atypical, SARS-CoV-2positive patients.

In this era of SARS-CoV-2 pandemic, it is important to rule out the acute surgical condition

\begin{abstract}
BACKGROUND: On March 11, 2020, the General Director of the World Health Organization has announced that according to the organization, the level of spread and severity of symptoms of coronavirus disease (COVID-19) is Organization stimulated more urgent and belligerent actions from the governments as the number of case reports studies on COVID-19 symptoms and treatment increased dramatically.

S A search was performed on two electronic databases: PubMed Central and Google Scholar, using consequences on the same are not fully examined.
\end{abstract}

CONCLUSION: The conclusion of the analyzed papers is that clinical practitioners in COVID-19 pandemic should carefully distinguish abdominal pain and other GI symptoms from COVID-19 manifestations and should exclude which needs emergency operation, having in mind that SARS-CoV-2 infection may be presented with abdominal pain and other Gl symptoms. To do so, for clinical practitioners, it is important to have sufficient information about the scope of gastrointestinal (GI) symptoms manifested in COVID-19-positive patients. Therefore, in the following parts of the paper, the available case reports regarding this topic are presented.

\section{Abdominal Pain in Adults with COVID-19}

At the beginning of the COVID-19 pandemic, the clinical features of the novel coronavirus were mainly described as respiratory. However, as the time passed, the understanding of the COVID-19 evolved and it was concluded that COVID-19 can cause multiple organ dysfunction. Namely, the variety of the symptoms of the novel COVID-19 has rapidly increased. According to Liu et al. [3], the typical initial symptoms of COVID-19 include fever, cough, and muscle pain or fatigue, while the less typical symptoms of the infection reported are heart palpitations, diarrhea, and headache.

Besides the manifestations on the respiratory system, the smell and taste disorders (anosmia and dysgeusia, respectively), GI symptoms of COVID-19, and abdominal pain are also reported as less typical symptoms. The chronic respiratory disease report as of 
May 30,2020 , in the USA, among 373,883 confirmed COVID-19 cases with data on individual symptoms, 28,443 have reported abdominal pain, which is $7.6 \%$ [4]. In addition, in this report, it is noted that nausea/vomiting was reported in 42,813 cases (or $11.5 \%$ ), while diarrhea was present in 72,039 cases (or 19.3\%) [4].

However, various authors suggest that GI symptoms may be underestimated and indicate that abdominal pain, diarrhea, nausea, vomiting, and lack of appetite, in some cases are presented before [5] or together with mild respiratory symptoms. Zang et al. [6] suggested that patients with GI symptoms had longer duration between symptom onset and viral clearance.

In the following table (Table 1), the reported cases of SARS-CoV-2-positive patients with abdominal pain are summarized. It is important to note that some of them had also other $\mathrm{Gl}$ symptoms, while others were without other GI symptoms. In addition, in regard to the localization of the abdominal pain, it can be concluded that most of the patients in the presented case reports experienced epigastric pain or diffused abdominal pain. Furthermore, significant number of patients has described pain in the right iliac fossa.

To sum up, although at the early stages of the pandemic, the papers focused on the clinical characteristics of COVID-19, classified the GI symptoms as uncommon [7], the authors of the presented case reports have shown that manifestation of the disease on the digestive tract can be challenging for diagnostics. Besides, it is noted that in these cases, a computed tomography (CT) on the abdomen is the most commonly used diagnostic technique, while the ultrasound scan can also give good information regarding diagnostics. However, on the abdominal $\mathrm{CT}$, in most of the cases, the lower parts of the lungs

Table 1: Summary of the case reports analyzed in adults

\begin{tabular}{|c|c|c|c|c|c|c|}
\hline S. No. & Case/author & Abdominal pain region & Other GI symptoms & Fever & CT abdomen & $\begin{array}{l}\text { CT chest (at presentation), (or chest X-ray done } \\
\text { instead) }\end{array}$ \\
\hline 1 & Widyadharma et al. [1] & $\begin{array}{l}\text { Persistent stabbing pain that } \\
\text { originates in the groin and } \\
\text { migrates to the abdomen, } \\
\text { pelvis, back, and chest }\end{array}$ & None & Yes & $\begin{array}{l}\text { Pulmonary ground-glass } \\
\text { opacification, pneumonia type of } \\
\text { consolidation, potential sigmoid } \\
\text { colitis, and distal descending colon }\end{array}$ & NA \\
\hline 2 & Saeed et al. [2] & Epigastric & Nausea, vomiting & No & Normal & Bilateral ground-glass opacities \\
\hline 3 & Saeed et al. [2] & Epigastric & Nausea, vomiting & Yes & Normal & Bilateral ground-glass opacities \\
\hline 4 & Saeed et al. [2] & Global & Nausea & Yes & Normal & Bilateral ground-glass opacities \\
\hline 5 & Saeed et al. [2] & Left iliac fossa & Nausea, vomiting & Yes & Normal & Bilateral ground-glass opacities \\
\hline 6 & Saeed et al. [2] & Right iliac fossa & Nausea & Yes & Normal & Bilateral ground-glass opacities \\
\hline 7 & Saeed et al. [2] & Global & Nausea, vomiting & No & Normal & Bilateral ground-glass opacities \\
\hline 8 & Saeed et al. [2] & Right iliac fossa & Nausea, vomiting & No & Cholecystitis & Normal \\
\hline 9 & Saeed et al. [2] & Right iliac fossa & Diarrhea & Yes & Appendicitis & Normal \\
\hline 10 & Saeed et al. [2] & Umbilical & Nausea & No & lleus & Normal \\
\hline 11 & Walpole et al. [14] & $\begin{array}{l}\text { Severe abdominal pain } \\
\text { (renal colic susp.) }\end{array}$ & Vomiting, diarrhea & Yes & Normal & $\begin{array}{l}\text { Multifocal peripheral patches of consolidation } \\
->3 \mathrm{~cm} \text { in diameter with air bronchograms } \\
\text { running through - in all but the left upper lobe }\end{array}$ \\
\hline 12 & Ahmed et al. [15] & $\begin{array}{l}\text { At first diffused, later } \\
\text { localized to the right lower } \\
\text { quadrant }\end{array}$ & Diarrhea, vomiting & Yes & $\begin{array}{l}\text { Diffuse paracolic gutters fat } \\
\text { stranding, mild free fluid, bilateral } \\
\text { mild pleural effusion with } \\
\text { consolidations, and filling defect } \\
\text { at superior mesentery vein that is } \\
\text { attributed to streaming artifact or } \\
\text { thrombosis }\end{array}$ & $\begin{array}{l}\text { Initial chest } X \text {-ray** normal; repeated chest } \\
\text { X-ray** showed bilateral infiltrates }\end{array}$ \\
\hline 13 & Ahmed et al. [16] & Right iliac fossa & Nausea, vomiting & Yes & Normal & Upper cut bilateral basal lung consolidation \\
\hline 14 & Ahmed et al.[16] & Right upper quadrant & None & No & Right hypochondria epiploic & Normal \\
\hline 15 & Ahmed et al. [16] & Epigastric & Nausea, vomiting & Yes & Normal & NA \\
\hline 16 & Abdalhadi et al. [17] & Right iliac fossa & Nausea, vomiting & No & Normal & $\begin{array}{l}\text { Bilateral patchy peripheral lung basal } \\
\text { consolidation and ground-glass attenuations }\end{array}$ \\
\hline 17 & Pazgan-Simon et al. [18] & Global & None & No & Normal & $\begin{array}{l}\text { Interstitial consolidations in the lower lobes of } \\
\text { both lung bases }\end{array}$ \\
\hline 18 & Voutsinas et al. [19] & Right lower quadrant & None & No & Normal & $\begin{array}{l}\text { Hazy ground-glass opacities in the dependent } \\
\text { portions of both lung bases }\end{array}$ \\
\hline 19 & Voutsinas et al. [19] & Flank pain & Nausea, vomiting & Yes & Normal & $\begin{array}{l}\text { Peripheral ground-glass opacities with } \\
\text { associated increased interstitial markings in } \\
\text { both lung bases }\end{array}$ \\
\hline 20 & Voutsinas et al. [19] & Abdominal pain & Diarrhea, blood stool & No & Mild sigmoid colitis & $\begin{array}{l}\text { Ground-glass opacification with a rounded } \\
\text { morphology in the periphery of the right lung base }\end{array}$ \\
\hline 21 & Voutsinas et al. [19] & Epigastric and flank pain & Nausea & No & Pyelonephritis & $\begin{array}{l}\text { Rounded ground-glass opacities in the } \\
\text { periphery of the imaged right lower lobe }\end{array}$ \\
\hline 22 & Mahan et al. [20] & Periumbilical pain & None & No & None & $\begin{array}{l}\text { Abdominal aorta showed thromboemboli, diffuse } \\
\text { bilateral ground-glass opacities in the lungs }\end{array}$ \\
\hline 23 & Gérald et al. [21] & $\begin{array}{l}\text { Epigastric pain and RUQ } \\
\text { sensitivity }\end{array}$ & Nausea & No & $\begin{array}{l}\text { Bilateral subpleural irregular lines } \\
\text { and scattered peribronchial ground- } \\
\text { glass opacities at both lung bases }\end{array}$ & NA \\
\hline 24 & Gérald et al. [21] & Epigastric pain & None & Yes & $\begin{array}{l}\text { No abdominal abnormal finding but } \\
\text { demonstrated bilateral subpleural } \\
\text { ground-glass opacities with } \\
\text { intralobular reticulations at the lung } \\
\text { bases }\end{array}$ & NA \\
\hline 25 & Gérald et al. [21] & $\begin{array}{l}\text { Diffuse abdominal pain } \\
\text { without guarding }\end{array}$ & Nausea and diarrhea & No & $\begin{array}{l}\text { Demonstrating predominantly right } \\
\text { lower lobe crazy-paving associating } \\
\text { ground-glass opacities and } \\
\text { interlobular reticulations }\end{array}$ & NA \\
\hline 26 & Purayil et al. [22] & Epigastric pain & Vomiting & Yes & $\begin{array}{l}\text { Ultrasound scan* of the abdomen } \\
\text { was normal }\end{array}$ & Chest X-ray ${ }^{* *}$ revealed bilateral infiltrates \\
\hline 27 & Altermanini et al. [23] & Epigastric pain & None & No & None & Normal \\
\hline
\end{tabular}


or the lungs bases are visible, which is important for detecting any abnormalities in these organs, too.

According to Ye et al. [8], the mechanisms that cause GI symptoms in COVID-19-positive patients can be different:

1. Direct infection of $\mathrm{Gl}$ cells - the expression and distribution of ACE2 in humans is a potential infection pathway for SARS-CoV-2. ACE2 is widely found in human small intestinal epithelial cells, especially in type II epithelial cells. In addition, high expression of ACE2 has been detected in the intestinal epithelial cells, the esophagus, and the lungs. Ye et al. suggested that the presence of GI symptoms in COVID-19 patients indicates that SARS-CoV-2 may invade target organs of the digestive tract through ACE2 receptors and cause primary damage. In addition, several authors indicate that SARS-CoV-2 is 10-20 times more transmissible than SARS-CoV. Furthermore, Ye et al. hypothesized that ACE2 expressing cells in humans, secretes large number of cytokines which induces cytokines' storm that can cause damage to multiple organs and may also cause immune cell death;

2. Gl damage caused by lung infection - which mainly refers to the effect called "gut-lung axis" which means that disorders of the GI flora affect the respiratory tract and vice versa, respiratory tract changes impact the digestive tract through immune regulation;

3. Gl symptoms caused by drug's side effects use of large amount of antibiotics (especially macrolides, cephalosporins, and $\beta$-lactam antibiotics), is the most common cause for diarrhea as a side effect in COVID-19-positive patients.

Furthermore, Perisetti et al. [9] suggested a classification of four pathogenic mechanisms that cause GI manifestations in COVID-19 patients:

1. Cytopathic effects - SARS-CoV-2 binds on ACE 2 receptors and enters the stomach and small intestine;

2. Gut inflammation - induced pro-inflammatory pathways with increased cytokine release and fecal calprotectin;

3. Altered gut microbiota - increased mTor activity, hypochlorhydria, altered gut-lungs axis;

4. Others - include drug-induced changes, preexisting condition worsening, and secondary infection.

In general, "after the entry into GI tract, SARS-CoV-2 can exert its cytopathic/inflammatory changes, which can potentially lead to visceral pain. If this is a somatic due to the involvement of the peritoneum or a referred pain is unknown" [9]. However, the exact mechanism of appearance of abdominal pain in COVID-19-positive patients is unclear.

Several case reports also indicate a correlation between COVID-19 and cholecystitis. Authors have presented case of COVID-19 that was associated with acalculous cholecystitis [10], [11], [12]. All patients in reported cases with this condition are aged over 60 years. This condition may lead to gallbladder ischemia, necrosis, and perforation that require emergency surgical operation. They suggested that pathophysiological mechanism is that SARS-CoV-2 binds to ACE-2 receptor in the liver, gallbladder, and bile ducts [13]. Systemic endotheliitis, hypercoagulability, antiphospholipid antibodies, and thrombotic microangiopathy are the other contributors to the occurrence of cholecystitis in COVID-19-positive patients. Furthermore, some reports describe patients with SARS-CoV-2 acute calculus cholecystitis [13] that has had no clinical manifestation of gallstones before this viral infection. The abdominal pain caused by cholecystitis is usually not the first manifestation of SARS-CoV-2 infection (for acalculous cholecystitis).

\section{Abdominal Pain and COVID-19 in Children}

Before the COVID-19 pandemic, few studies have focused on the correlation between viral infections (cytomegalovirus, Epstein-Barr virus, hepatitis A virus, and human herpes virus) and acalculous cholecystitis in children [24], [25], [26], [27]. According to these studies, diagnosis of acute cholecystitis may be challenging. Supposed pathogenic mechanism in these cases is direct invasion or inflammation triggered by bile stasis [26].

The literature also provides papers and case reports that depict patients that had COVID-19 manifested with pediatric abdominal pain. These cases can be challenging for diagnostics, in the same way as with adults. The available cases are presented in Table 2.

In the analyzed case reports, it is outlined that in COVID-19 pediatric patients with GI symptoms, adequate imaging studies (ultrasound and CT) should be done to exclude the acute abdomen. The $\mathrm{Gl}$ symptoms, including abdominal pain, may be only a presentation of the SARS-CoV-2 infection without the need for emergency surgical treatment. Furthermore, some studies prove that the surgical treatment in these patients may deteriorate the condition.

\section{Treatment}

The key point in treatment of COVID-19 patients with abdominal pain is to exclude acute surgical suffering. Besides physical examination, adequate imaging studies are necessary.

In adults, the reported cases show that abdominal pain may manifest before respiratory signs 
Table 2: Summary of the case reports analyzed in children

\begin{tabular}{|c|c|c|c|c|c|c|c|c|c|}
\hline $\begin{array}{l}\text { S. } \\
\text { No. }\end{array}$ & Case/author & $\begin{array}{l}\text { Age and } \\
\text { gender }\end{array}$ & $\begin{array}{l}\text { Medical } \\
\text { history }\end{array}$ & $\begin{array}{l}\text { Abdominal } \\
\text { pain }\end{array}$ & Other GI symptoms & Fever & CT abdomen & CT chest & $\begin{array}{l}\text { SARS-CoV-2 } \\
\text { PCR }\end{array}$ \\
\hline 1 & Harwood et al. [28] & $\begin{array}{l}14 \text { years, } \\
\text { Female }\end{array}$ & $\begin{array}{l}\text { No } \\
\text { underlying } \\
\text { medical } \\
\text { conditions }\end{array}$ & $\begin{array}{l}\text { Central } \\
\text { abdominal } \\
\text { pain which } \\
\text { migrated } \\
\text { to the right } \\
\text { iliac fossa }\end{array}$ & None & Yes & $\begin{array}{l}\text { Abdominal ultrasound scan } \\
\text { demonstrated mesenteric adenitis } \\
\text { without free fluid and chest X-ray } \\
\text { was unremarkable }\end{array}$ & $\begin{array}{l}12 \mathrm{~h} \text { later, urgent computed } \\
\text { tomography scan of the } \\
\text { chest and abdomen } \\
\text { revealed diffuse intra- and } \\
\text { interlobar thickening } \\
\text { consistent with SARS- } \\
\text { CoV-2 infection and no } \\
\text { intra-abdominal pathology }\end{array}$ & Negative \\
\hline 2 & Harwood et al. [28] & 3 years, Male & Nil & $\begin{array}{l}\text { Abdominal } \\
\text { pain }\end{array}$ & $\begin{array}{l}\text { Diarrhea and } \\
\text { vomiting }\end{array}$ & Yes & $\begin{array}{l}\text { Revealed perforated appendicitis } \\
\text { with intra-abdominal collections }\end{array}$ & NA & Positive \\
\hline 3 & Tullie et al. [29] & 4 years, Male & $\begin{array}{l}\text { Autism } \\
\text { spectrum } \\
\text { disorder }\end{array}$ & $\begin{array}{l}\text { Abdominal } \\
\text { pain }\end{array}$ & $\begin{array}{l}\text { Diarrhea and } \\
\text { vomiting }\end{array}$ & Yes & $\begin{array}{l}\text { US abdomen: Mesenteric } \\
\text { lymphadenopathy, terminal ileitis, } \\
\text { normal appendix }\end{array}$ & NA & Positive \\
\hline 4 & Tullie et al. [29] & 5 years, Male & Nil & $\begin{array}{l}\text { Abdominal } \\
\text { pain }\end{array}$ & $\begin{array}{l}\text { Diarrhea and } \\
\text { vomiting }\end{array}$ & Yes & $\begin{array}{l}\text { US abdomen: Mesenteric } \\
\text { lymphadenopathy and free fluid } \\
\text { in right iliac fossa, no bowel wall } \\
\text { thickening, normal appendix }\end{array}$ & NA & Negative \\
\hline 5 & Tullie et al. [29] & 8 years, Male & Nil & $\begin{array}{l}\text { Abdominal } \\
\text { pain }\end{array}$ & $\begin{array}{l}\text { Diarrhea and } \\
\text { vomiting }\end{array}$ & Yes & $\begin{array}{l}\text { US abdomen: Echogenic fat and } \\
\text { mild terminal ileal thickening, } \\
\text { appendix not visualized, no } \\
\text { significant lymphadenopathy }\end{array}$ & NA & Positive* \\
\hline 6 & Tullie et al. [29] & $\begin{array}{l}11 \text { years, } \\
\text { Female }\end{array}$ & Mild asthma & $\begin{array}{l}\text { Abdominal } \\
\text { pain }\end{array}$ & $\begin{array}{l}\text { Diarrhea and } \\
\text { vomiting }\end{array}$ & Yes & $\begin{array}{l}\text { US abdomen: Bowel wall thickening } \\
\text { involving ileocecal junction with } \\
\text { mesenteric lymphadenopathy. } \\
\text { Appendix not seen CT abdomen: } \\
\text { Fluid-filled appendix with } \\
\text { appendicolith but no inflammation. } \\
\text { Thickened cecum and multiple } \\
\text { enlarged mesenteric lymph nodes }\end{array}$ & NA & Positive \\
\hline 7 & Tullie et al. [29] & $\begin{array}{l}12 \text { years, } \\
\text { Female }\end{array}$ & Nil & $\begin{array}{l}\text { Abdominal } \\
\text { pain }\end{array}$ & $\begin{array}{l}\text { Diarrhea and } \\
\text { vomiting }\end{array}$ & Yes & $\begin{array}{l}\text { US abdomen: Multiple enlarged } \\
\text { lymph nodes in right lower quadrant. } \\
\text { Appendix not seen } \\
\text { CT abdomen: Non-inflamed } \\
\text { retrocecal appendix, terminal } \\
\text { ileal thickening and mesenteric } \\
\text { lymphadenopathy }\end{array}$ & NA & Positive \\
\hline 8 & Tullie et al. [29] & 14 years, Male & Nil & $\begin{array}{l}\text { Abdominal } \\
\text { pain }\end{array}$ & $\begin{array}{l}\text { Diarrhea and } \\
\text { vomiting }\end{array}$ & Yes & $\begin{array}{l}\text { US abdomen: Inflammatory changes } \\
\text { in ileocecal region associated with } \\
\text { lymphadenopathy. No features of } \\
\text { appendicitis. (Nb. This was performed } \\
\text { after the CT to confirm findings) } \\
\text { CT abdomen (non-contrast): } \\
\text { Inflammatory change in the right } \\
\text { iliac fossa with matted bowel loops. } \\
\text { Focal collection and enlarged } \\
\text { mesenteric lymph nodes. Collapsed } \\
\text { bowel loops, no visible collection or } \\
\text { evidence of appendicitis }\end{array}$ & NA & Positive \\
\hline 9 & Tullie et al. [29] & 15 years, Male & Nil & $\begin{array}{l}\text { Abdominal } \\
\text { pain }\end{array}$ & $\begin{array}{l}\text { Diarrhea and } \\
\text { vomiting }\end{array}$ & Yes & $\begin{array}{l}\text { US abdomen: Inflammatory change } \\
\text { and echogenic fat in right iliac fossa, } \\
\text { mesenteric lymphadenopathy. } \\
\text { Appendix not visualized. } \\
\text { CT abdomen: Calcified appendicolith } \\
\text { in non-inflamed appendix. } \\
\text { Thickening of terminal ileum } \\
\text { consistent with terminal ileitis }\end{array}$ & NA & Negative \\
\hline 10 & Tullie et al. [29] & $\begin{array}{l}16 \text { years, } \\
\text { Female }\end{array}$ & Nil & $\begin{array}{l}\text { Abdominal } \\
\text { pain }\end{array}$ & $\begin{array}{l}\text { Diarrhea and } \\
\text { vomiting }\end{array}$ & Yes & $\begin{array}{l}\text { US abdomen: Terminal } \\
\text { ileal inflammation with local } \\
\text { lymphadenopathy, normal appendix }\end{array}$ & NA & Negative \\
\hline 11 & Saleh et al. [30] & 4 months, Male & $\begin{array}{l}\text { Ontogenesis } \\
\text { imperfecta }\end{array}$ & $\begin{array}{l}\text { Abdominal } \\
\text { tenderness }\end{array}$ & $\begin{array}{l}\text { Poor feeding, } \\
\text { bilious vomiting }\end{array}$ & Yes & $\begin{array}{l}\text { Coffee bean sign in the left upper } \\
\text { quadrant viewed on abdominal X-ray }\end{array}$ & $\begin{array}{l}\text { Typical lesions for SARS- } \\
\text { CoV-2 on chest }\end{array}$ & Positive \\
\hline 12 & Saleh et al. [30] & 10 years, Male & Nil & $\begin{array}{l}\text { Abdominal } \\
\text { pain, } \\
\text { tenderness, } \\
\text { and } \\
\text { guarding }\end{array}$ & No & No & US: Signs of appendicitis & $\begin{array}{l}\text { Highly suggestive for } \\
\text { COVID-19 }\end{array}$ & Positive \\
\hline 13 & Saleh et al. [30] & $\begin{array}{l}5 \text { years, } \\
\text { Female }\end{array}$ & Nil & $\begin{array}{l}\text { Abdominal } \\
\text { pain, } \\
\text { tenderness, } \\
\text { and } \\
\text { guarding }\end{array}$ & Vomiting & Yes & US: Signs of appendicitis & $\begin{array}{l}\text { Typical lesions for SARS- } \\
\text { CoV-2 on chest }\end{array}$ & $\begin{array}{l}\text { NA-contact } \\
\text { with SARS- } \\
\text { CoV-2-positive } \\
\text { patients }\end{array}$ \\
\hline 14 & Saleh et al. [30] & 45 days, Male & $\begin{array}{l}\text { Cerebral } \\
\text { palsy, } \\
\text { seizures }\end{array}$ & $\begin{array}{l}\text { Abdominal } \\
\text { distention } \\
\text { and } \\
\text { irritability }\end{array}$ & Oral intolerance & No & Abdominal X-ray: Coffee bean sign & $\begin{array}{l}\text { Typical lesions for SARS- } \\
\text { CoV-2 on chest }\end{array}$ & Positive \\
\hline
\end{tabular}

of SARS-CoV-2 infection, and therefore, adequate imaging studies are required. It can be noted that in these cases, abdominal CT is the most commonly used diagnostic technique, while the ultrasound scan can also give good information regarding the diagnosis.
However, on the abdominal CT, in most of the cases, the lower parts of the lungs or the lungs bases are visible, which is important for detecting any abnormalities in these organs, also. This is the advantage when using abdominal CT scan as a diagnostic tool. 
In addition, in adults when acute abdomen is excluded, treatment is based on analgesia, and in some of the presented cases, opioid analgesics were needed for relieving pain. The additional treatment is based on the COVID-19 Protocols and Guidelines. Furthermore, the use of probiotics may improve Gl symptoms in patients diagnosed with COVID-19. According to Falch et al. [31], most appropriate treatment of abdominal pain when the need for surgery is ruled out includes opioid or non-opioid analgesics. Opioid analgesics bind to opioid receptors both in the central nervous system and in peripheral tissues to provide pain relief. Non-opioid analgesic agents are divided into acidic which mainly accumulate in tissues with a low $\mathrm{pH}$ (such as tissue with active inflammatory processes, the kidneys, and the stomach) and non-acid anti-pyretic analgesics which distribute to all tissues. The intensity of pain is crucial for determining the type of analgesics that need to be used. The administration of the drugs largely depends on the estimated potential for enteric absorption of the delivered agent [31].

Mattone et al. suggested that in the cases of COVID-19-positive patients that developed acute cholecystitis, although laparoscopic cholecystectomy is considered the gold standard, Tokyo Guidelines advice to delay surgical operation and to perform the percutaneous gallbladder drainage for surgically highrisk patients with acute cholecystitis and comorbidities.

As presented in the case reports in the previous section, in children, the abdominal pain and other GI signs are usually presented later, during hospital stay of the patients, and often mimicking atypical appendicitis or volvulus. Therefore, in the case reports described above, when explorative laparotomy or laparoscopy was executed, the intraoperative finding was peritoneal lymphadenopathy and/or serous peritoneal effusion. According to Hijaz et al., "... pediatric patients in general are at risk for receiving less than optimal analgesia. In the setting of acute AP (author remark: Abdominal pain), providers are often concerned about the possibility that strong analgesia (e.g., opioids) may mask symptoms and result in complications and increased morbidity. Several prospective, randomized studies have shown that judicious use of analgesia may enhance diagnostic accuracy by permitting a more thorough physical examination. It appears that opioids may be used to treat acute AP in children without delaying the diagnosis" [32].

\section{Conclusion}

According to the literature review, abdominal pain may be the first sign of SARS-CoV-2 infection in adults, occasionally without any respiratory symptoms and fever. In the further development of the disease, the abdominal pain relievers and the other respiratory symptoms prevail. Acute acalculous cholecystitis may be present in SARS-CoV-2-positive patient with severe clinical manifestations.

In the described case reports of children, the situation is different. Namely, in the analyzed cases, the abdominal pain and GI symptoms worsened after the patients were diagnosed with SARS-CoV-2 infection and were hospitalized due to the severity of other symptoms.

Overriding conclusion of the analyzed papers is that clinical practitioners in COVID-19 pandemic should carefully distinguish abdominal pain and other GI symptoms from COVID-19 manifestations and should exclude acute surgical condition.

\section{References}

1. Widyadharma PE, Sari NN, Pradnyaswari KE, Yuwana KT, Adikarya IP, Tertia C, et al. Pain as clinical manifestations of COVID-19 infection and its management in the pandemic era: A literature review. Egypt J Neurol Psychiatr Neurosurg. 2020;56(1):121. https://doi.org/10.1186/s41983-020-00258-0

PMid:33390724

2. Saeed U, Sellevoll HB, Young VS, Sandbaek G, Glomsaker T, Mala T. COVID-19 may present with acute abdominal pain. Br J Surg. 2020;107(7):e186-7. https://doi.org/10.1002/bjs.11674 PMid:32343396

3. Liu K, Fang YY, Deng Y, Liu W, Wang MF, Ma JP, et al. Clinica characteristics of novel Coronavirus cases in tertiary hospitals in Hubei Province. Chin Med J (Engl). 2020;133(9):1025-31. https://doi.org/10.1097/cm9.0000000000000744

PMid:32044814

4. Stokes EK, Zambrano LD, Anderson KN, Marder EP, Raz KM, Felix SE, et al. Coronavirus disease 2019 case surveillanceUnited States, January 22-May 30, 2020. MMWR Morb Mortal Wkly Rep. 2020;69(24):759-65. https://doi.org/10.15585/mmwr. mm6924e2

PMid:32555134

5. Amaral LTW, Brito VM, Beraldo GL, Fonseca EK, Yokoo P, Talans A, Filho MO, et al. Abdominal symptoms as initial manifestation of COVID-19: A case series. Einstein (São Paulo). 2020;18:eRC5831. https://doi.org/10.31744/ einstein_journal/2020rc5831 PMid:33084795

6. Zang J, Garrett S, Sun J. Gastrointestinal symptoms, pathophysiology and treatment in COVID-19. Genes Dis. 2020; doi: 10.1016/j.gendis.2020.08.013 [Epub ahead of print]. PMid:33521210

7. Guan W, Ni Z, Hu Y, Liang W, Ou C, He J, et al. Clinical characteristics of Coronavirus disease 2019 in China. N Engl J Med. 2020;382(18):1708-20.

8. Ye $Q$, Wang $B$, Zhang $T, X u$ J, Shang S. The mechanism and treatment of gastrointestinal symptoms in patients with COVID-19. Am J Physiol Gastrointest Liver Physiol. 2020;319(2):G245-52. PMid:32639848

9. Perisetti A, Goyal H, Gajendran M, Boregowda U, Mann R, Sharma N. Prevalence, mechanisms, and implications 
of gastrointestinal symptoms in COVID-19. Front Med. 2020;7:588711. https://doi.org/10.3389/fmed.2020.588711 PMid:33195352

10. Ying M, Lu B, Pan J, Lu G, Zhou S, Wang D, et al. COVID-19 with acute cholecystitis: A case report. BMC Infect Dis. 2020;20(1):437. https://doi.org/10.1186/s12879-020-05164-7 PMid:32571224

11. Mattone E, Sofia M, Schembari E, Palumbo V, Bonaccorso R, Randazzo V, et al. Acute acalculous cholecystitis on a COVID19 patient: A case report. Ann Med Surg (Lond). 2020;58:73-5. https://doi.org/10.21203/rs.3.rs-42230/v1 PMid:32895611

12. Balaphas A, Gkoufa K, Meyer J, Peloso A, Bornand A, McKee TA, et al. COVID-19 can mimic acute cholecystitis and is associated with the presence of viral RNA in the gallbladder wall. J Hepatol. 2020;73(6):1566-8. https://doi.org/10.1016/j. jhep.2020.08.020

PMid:32890595

13. Famularo G, Spada PL. COVID-19-related cholecystitis. Clin Res Hepatol Gastroenterol. 2021;45(2):101635. PMid:33588314

14. Walpole SC, McHugh R, Samuel J, Schmid ML. COVID-19 presenting as severe, persistent abdominal pain and causing late respiratory compromise in a 33-year-old man. BMJ Case Rep. 2020;13(6):e236030. https://doi.org/10.1136/ bcr-2020-236030

PMid:32546557

15. Ahmed AO, Mohamed SF, Saleha AO, Al-Shokria SD, Ahmedb K, Mohamed MF. Acute abdomen-like-presentation associated with SARS-CoV-2 infection. IDCases. 2020;21:e00895. https:// doi.org/10.1016/j.idcr.2020.e00895 PMid:32691004

16. Ahmed AO, Badawi M, Ahmed K, Mohamed MFH. Case report: COVID-19 masquerading as an acute surgical abdomen. Am J Trop Med Hyg. 2020;103(2):841-3. https://doi.org/10.4269/ ajtmh.20-0559 PMid:32524962

17. Abdalhadi A, Alkhatib M, Mismar AY, Awouda W, Albarqouni L. Can COVID-19 present like appendicitis? IDCases. 2020;21:e00860. https://doi.org/10.1016/j.idcr.2020.e00860 PMid:32523872

18. Pazgan-Simon M, Rorat M, Buczyńska I, Zińczuk A, Simon K. Gastrointestinal symptoms as the first, atypical indication of severe acute respiratory syndrome Coronavirus 2 infection. Pol Arch Intern Med. 2020;130(4):338-9. https://doi.org/10.20452/ pamw.15278 PMid:32250094

19. Voutsinas N, Toussie D, Jacobi A, Bernheim A, Chung M. Incidental $\mathrm{CT}$ findings in the lungs in COVID-19 patients presenting with abdominal pain. Clin Imaging. 2020;67:1-4. https://doi.org/10.1016/j.clinimag.2020.05.021 PMid:32492557

20. Mahan K, Kabrhel C, Goldsmith AJ. Abdominal pain in a patient with COVID-19 infection: A case of multiple thromboemboli. Am J Emerg Med. 2020;38(10):2245.e3-5. https://doi.org/10.1016/j. ajem.2020.05.054

\section{PMid:32513452}

21. Gérald G, Frandon JA, Vendrell JF. COVID-19 patients presenting with afebrile acute abdominal pain. Clin Med. 2020;20(3):e4-6. https://doi.org/10.7861/clinmed.2020-0150 PMid:32341078

22. Purayil N, Sirajudeen J, Naushad VA, Mathew J. COVID-19 presenting as acute abdominal pain: A case report. Cureus. 2020;12(8):e9659. https://doi.org/10.7759/cureus.9659 PMid:32923256

23. Altermanini M, Habib MB, Elzouki AN. A challenging case of COVID-19 infection presented with isolated acute abdominal pain: A case report and literature review. SAGE Open Med Case Rep. 2020;9:1-5. https://doi.org/10.1177/2050313×20983211 PMid:33633860

24. Gora-Gebka M, LiberekA, Bako W, Szarszewski A, Kamińska B, Korzon M. Acute acalculous cholecystitis of viral etiology-a rare condition in children? J Pediatr Surg. 2008;43(1):e25-7. https:// doi.org/10.1016/j.jpedsurg.2007.10.073

PMid:18206441

25. Strehle EM, De Alwis Y, Saleem M. Epstein-Barr virus-associated acute cholecystitis in a teenager. Ultrasound. 2014;22(2):123-5. https://doi.org/10.1177/1742271x13513223 PMid:27433206

26. Poddighe D, Sazonov V. Acute acalculous cholecystitis in children. World J Gastroenterol. 2018;24(43):4870-9. https:// doi.org/10.3748/wjg.v24.i43.4870 PMid:30487697

27. Langenohl R, Young S, Couperus K. Acute acalculous cholecystitis from infection with Epstein-Barr virus in a previously healthy child: A case report. Clin Pract Cases Emerg Med. 2020;4(3):393-6. https://doi.org/10.5811/cpcem.2020.4.46301 PMid:32926694

28. Harwood R, Partridge R, Minford J, Almond S. Paediatric abdominal pain in the time of COVID-19: A new diagnostic dilemma. J Surg Case Rep. 2020;2020:rjaa337. https://doi. org/10.1093/jscr/rjaa337 PMid:32994918

29. Tullie L, Ford K, Bisharat M, Watson T, Thakkar H, Mullassery D, et al. Gastrointestinal features in children with COVID-19: An observation of varied presentation in eight children. Lancet Child Adolesc Health. 2020;4(7):e19-20. https://doi.org/10.1016/ s2352-4642(20)30165-6 PMid:32442420

30. Saleh R, Rahimi H, Javadi N, Amini S, Saeidi S, Pourmoghaddas, Z. Abdominal signs and symptoms of COVID19 in children. Arch Pediatr Infect Dis. 2021;9(1):e107259. https://doi.org/10.5812/pedinfect.107259

31. Falch C, Vicente D, Häberle H, Kirschniak A, Müller S, Nissan A, et al. Treatment of acute abdominal pain in the emergency room: A systematic review of the literature. Eur J Pain. 2014;18(7):90213. https://doi.org/10.1002/j.1532-2149.2014.00456.x PMid:24449533

32. Hijaz NM, Friesen CA. Managing acute abdominal pain in pediatric patients: Current perspectives. Pediatric Health Med Ther. 2017;29(8):83-91. https://doi.org/10.2147/phmt.s120156 PMid:29388612 